\title{
ANOTHER DivorCe: THE PDL IN 2010
}

\author{
David Hine and Davide Vampa
}

This chapter analyzes the power struggle inside the Popolo della Libertà (PdL, People of Liberty), which reached a crisis in the summer of 2010 , leading to the secession of about 10 percent of its parliamentarians to form a new party, Futuro e Libertà per l'Italia (FLI, Future and Freedom for Italy). First, it traces the process by which the new group emerged, explaining in particular the personal tensions between Silvio Berlusconi and Gianfranco Fini, which were the immediate cause. It seeks to provide an actor-centered analysis of the motivations of those who followed Fini into the new group at the parliamentary level, and it provides some pointers to the probable impact of the split on the PdL as an organization. Finally, it assesses the position reached at the conclusion of the vote of confidence held on 14 December 2010: a vote that Berlusconi won by the narrow margin of three votes in the Chamber of Deputies. The vote appeared to leave both leaders wounded and the center-right coalition seriously weakened. It gave Berlusconi a temporary respite from the acute instability that the coalition had suffered throughout the year, but it left unresolved the outcome of the broader power struggle between the two leaders.

The issues that led to the split concerned both the succession to Berlusconi and the nature and ethos of the PdL. Berlusconi's style of party leadership-variously described as monarchical, plebiscitary, padronale-is a marked break with the bargained negotiation between parties, factions, and territories that has been the dominant style of post-war Italian democracy. As a result, Berlusconi has repeatedly faced divorces, and while 2010 saw the formal end of his marriage to

Notes for this chapter begin on page 82 . 
Veronica Lario, much attention has also been focused on his political splits over the years. In all three periods as prime minister, Berlusconi has been challenged by one or more of the groups with whom he has been allied, as they have sought to contain his power. In 1994, it was the Lega Nord (LN, Northern League). In 2005, it was the Unione dei Democratici Cristiani e di Centro (UDC, Union of Christian and Center Democrats) and, ambivalently, the Alleanza Nazionale (AN, National Alliance). In 2010, the opposition came from within Berlusconi's own party-mainly, although not entirely, from part of the AN group that had been brought into the PdL in the 2009 merger. $^{1}$

In essence, the challenge played out by the prime minister's rivals and critics on the center-right can be seen as a continuing effort to constrain the capacity of a would-be plebiscitary leader to appeal directly to the electorate. Given what Berlusconi represents, and given the compelling evidence that he is in politics at least partly to serve his own personal ends, there are many reasons why advocates of the democratic process might worry if such an appeal succeeded. But for allies and rivals on the center-right, the main concern is a cruder one: the stronger Berlusconi becomes, the less he will allow power to be dispersed across the coalition in a negotiable way. To this charge, Berlusconi would respond, first, that, in any "normal" democracy, power would not be dispersed in the way that it is done in Italy; second, that his own allies, let alone his enemies, regularly play what is in effect a negative-sum game to restrict his power; and, third, that his political mission is to make Italy a normal democracy by making it a more purposive one. This chapter does not enter into the normative aspects of this debate. Exactly when the allocation of intra-party and intra-coalition power is a positive-sum game, as opposed to a zerosum or even negative-sum game, is an interesting question, but not one that needs to detain us for long in the case of the Italian centerright. Consistently, there are enough players who take the view that their own power is enhanced when Berlusconi is weakened to ensure that a key repertoire of action includes constraining behavior.

\section{The Formation of Futuro e Libertà per l'Italia}

The timeline leading to the formation of the FLI is well-known. In April, after months of simmering arguments, a violent public exchange of insults took place between Berlusconi and Fini at the PdL national council, an event all the more undignified as it involved two of the highest officials of the Italian state. Shortly afterward, and evidently with Fini's blessing, Italo Bocchino announced the creation of a new 
foundation, Generazione Italia (Generation Italy), the clear purpose of which was to rally dissatisfied members of the PdL around a faction that could prepare itself for a split, should it become necessary. On 29 July, three of Fini's close party allies (Bocchino, Carmelo Briguglio, and Fabio Granata) were referred by the presidency of the PdL (and hence by Berlusconi himself) to the probiviri del comitato di coordinamento (a nine-person disciplinary panel). The probiviri met in September and requested that the three submit a memorandum of defense against charges of party disloyalty by 21 October, although by then the matter was irrelevant. Immediately after the presidency's decision, the new FLI parliamentary group was formed. Three days later, a similar group was formed in the Senate. ${ }^{2}$ That Fini was also the target of the probiviri was not in doubt. A document released by the presidency of the party described Fini's behavior as "incompatible with the founding principles of the PdL." 3

Nevertheless, Fini remained circumspect about what exactly he had created, continuing to refer to the FLI as a parliamentary group or a foundation rather than a full-blown party. ${ }^{4}$ He was even more cautious about the new group's relationship with the governing coalition, insisting that his parliamentarians had been elected by voters on a program to which they would remain loyal. Therefore, in Fini's eyes, the FLI would not be responsible for a government breakdown, but neither would it necessarily support proposals that were not in the 2008 electoral program. The latter included most sensitively the socalled processo breve (short trial), that is, the government's proposal to shorten the time limits within which prosecution cases had to be completed. If the government made this issue a confidence matter and fell, Fini argued, the government, not the FLI, would be responsible.

The size of the rebellion may have taken Berlusconi by surprise, as it certainly did the two ex-AN hawks Maurizio Gasparri and Ignazio La Russa, who had apparently advised the prime minister that the secessionists could be contained. In April, Generazione Italia appeared to have only 31 deputies and senators in its ranks. ${ }^{5}$ By August there were 45,35 of whom were now in the Chamber of Deputies. Given the size of the government's majority (340 out of 630), ${ }^{6}$ they henceforth appeared to hold the balance.

Most of the secessionists were originally from the AN component elected in 2008. In the Chamber, only 2 of the 35 deputies (Chiara Moroni and Benedetto della Vedova) came from Forza Italia (Forward Italy) and not AN origins. However, as table 1.1 shows, the composition of the Chamber changed further in the last five months of the year, with defections within the FLI group itself during the confidence vote of 14 December. In the Senate, the only ex-Forza Italia recruit to 
TABLE 1.1 Change in the composition of the Chamber of Deputies and the Senate, July-December 2010, and the no confidence motion on 14 December 2010

\begin{tabular}{|c|c|c|c|c|c|c|c|}
\hline \multirow[b]{2}{*}{ Group } & \multirow[b]{2}{*}{$\begin{array}{l}1 \text { July } \\
2010\end{array}$} & \multirow[b]{2}{*}{$\begin{array}{l}1 \text { Oct. } \\
2010\end{array}$} & \multirow[b]{2}{*}{$\begin{array}{l}15 \text { Nov. } \\
2010\end{array}$} & \multirow[b]{2}{*}{$\begin{array}{l}13 \text { Dec. } \\
2010\end{array}$} & \multicolumn{3}{|c|}{$\begin{array}{l}\text { No Confidence Motion } \\
14 \text { December } 2010\end{array}$} \\
\hline & & & & & Yes & No & $\begin{array}{l}\text { Absent, } \\
\text { No Vote }\end{array}$ \\
\hline PdL & 272 & 236 & 234 & 235 & - & 235 & - \\
\hline FLI & - & 35 & 37 & 36 & 31 & 3 & $2^{*}$ \\
\hline LN & 59 & 59 & 59 & 59 & - & 59 & - \\
\hline MISTO & 31 & 35 & 35 & 35 & 24 & 17 & 3 \\
\hline ApI & 8 & 6 & 6 & 6 & 6 & - & - \\
\hline$M p A$ & 5 & 5 & 5 & 5 & 5 & - & - \\
\hline $\begin{array}{l}\text { Noi Sud Libertà } \\
\text { e Autonomia, } \\
\text { I Popolari di } \\
\text { Italia Domani }\end{array}$ & $\begin{array}{ll}\text { tà } & 6 \\
a, & \\
\text { i } & \\
\text { ni } & \end{array}$ & 6 & 11 & 12 & - & 11 & 1 \\
\hline$L D$ & 3 & 3 & 3 & 3 & 2 & 1 & - \\
\hline $\begin{array}{l}\text { Repubblicani } \\
\text { Azionisti }\end{array}$ & 3 & 3 & 3 & 3 & 1 & 2 & - \\
\hline $\begin{array}{l}\text { Minoranze } \\
\text { Linguistiche }\end{array}$ & 3 & 3 & 3 & 3 & 1 & - & 2 \\
\hline Indipendenti & 3 & 9 & 4 & 5 & 2 & 3 & - \\
\hline UdC & 38 & 35 & 35 & 35 & 35 & - & - \\
\hline PD & 206 & 206 & 206 & 206 & 206 & - & - \\
\hline IdV & 24 & 24 & 24 & 22 & 22 & - & - \\
\hline Total & 630 & 630 & 630 & 630 & 311 & 314 & 5 \\
\hline
\end{tabular}

*The president of the Chamber does not participate in the vote.

Source: Chamber of Deputies, http://www.camera.it.

the FLI was Barbara Contini. Moreover, although the secession was larger than most expected, it still involved only about one-third of the AN members who had been elected in 2008.

However cautious Fini had been initially, the events that quickly followed the formation of the FLI made any turning back impossible. This was ensured by the ferocious press campaign waged by Libero and Il Giornale against Fini over his hapless brother-in-law's property venture in Monaco (i.e., the alleged purchase at below cost of an apartment formerly belonging to the AN). The attacks also made it inconceivable that Fini could ever inherit the leadership of the PdL. 
Think tanks were key to Fini's strategy. FareFuturo (MakeFuture), founded in 2007, was a means of carving out a distinctive identity for Fini's followers, both in policy matters and organizationally. It mounted an energetic program of conferences, workshops, and courses, linked to increasingly direct attacks on Berlusconi himself. Initially, the purpose was intellectual and policy leadership, but by 2010, the program needed a stronger presence on the ground. Generazione Italia became that presence and was quickly transformed into an organization with the characteristics of a real political party with full territorial articulation. By October, there were reported to be 15,000 members and 900 circles, each claiming a minimum of 10 members. The director of Generazione Italia, Gianmario Mariniello, claimed that half of this total were from the AN, 20 percent were from Forza Italia, and 30 percent were new to politics. ${ }^{?}$

\section{Explaining the Split between Leaders}

The split between Fini and Berlusconi has its origins both in the events that led to the creation of the PdL and in what followed the election of 2008. The objective of a single party for the center-right had been long-standing but was not thought feasible, until Berlusconi suddenly revitalized it in November 2007 in his improvised discorso del predellino (speech made from the step-predellino-of his car), in which he called for the formation of the PdL. Fini's initial response was that the AN was not ready to merge itself into such an uncertain project. ${ }^{8}$ The single center-right party quickly transmuted into a "People" (in the populist terminology beloved of Berlusconi) and clashed even more strongly with Fini's aspiration to retain a distinct organizational and cultural identity for his own movement within the center-right. Nevertheless, the pressure of events leading to the fall of the Prodi government hastened developments. As the election approached, Fini agreed, probably reluctantly, to join a single center-right list of candidates (known, in fact, as the People of Liberty), which, in the months following the election, became a single party at the national level.

The explanation for Fini's about-turn seems to lie in the leadership rivalries within the AN. However secure Fini was as the AN's leader, many of the party's senior officials saw the merged party as a platform to pursue their own ambitions on a wider stage, where opportunities were potentially much greater than in the AN. Bocchino has stressed that, notwithstanding Fini's uncontested leadership, a large part of the party would have been alienated by any serious falling-out with Berlusconi ahead of a general election in which they expected to do well, if not very well. ${ }^{9}$ As we have seen, the majority of the AN did indeed remain 
with the PdL, suggesting that Bocchino is right. In this sense, in using the attractions of a large party stage to absorb the great majority of the post-fascist establishment, Berlusconi was completing an operation to rationalize the Italian right that went back almost 20 years to the incorporation of the Movimento Sociale Italiano (MSI, Italian Social Movement) into the zone of democratic respectability in 1993.

Fini's room for maneuver in 2008 therefore looks to have been limited. His acceptance of a merger may have been influenced by the hope that the loose and charismatically led PdL could be transformed into something more solid and structured, and closer to the more conventional center-right parties in Western Europe, but this institutionalization did not materialize. ${ }^{10}$ Ever since 1994, first Forza Italia and then the PdL had lived in a state of permanent mobilization, and this served Berlusconi's ends as the leader of these parties. In the year and a half that followed the merger, Fini and his followers became acutely aware that there would be no normalization and that charismatic and centralized leadership would continue to hold sway.

It was not just organizational issues that were at stake, however. Fini seemed to have made a tactical error in accepting the role of president of the Chamber of Deputies. By taking himself out of frontline partisan politics, he found himself in the awkward position of defender of the rights of Parliament against a government in regular conflict with the legislature. Clearly, there is much to be gained, for someone with Fini's past, in occupying major offices of state. His period as minister of foreign affairs (2004-2006) and, even more so, his role as president of the Chamber gave Fini a level of democratic credibility that he had never previously enjoyed. Some of his speeches made in the latter capacity suggest that he took to the role of constitutional guarantor with unexpected relish. He certainly did not hesitate to criticize the government-of which he was still, by electoral mandate, nominally a part-for its allegedly excessive use of confidence votes and decree laws, hardly a new theme in Italian constitutional controversy, but not one from which Fini shied away. ${ }^{11}$

Beyond Parliament, moreover, it was clear that Fini was carving out a new identity for himself as a defender of civil rights, particularly the rights of immigrants. He was also a surprising recruit to the liberal cause on right-to-life and lifestyle issues, such as in vitro fertilization, the morning-after pill, living wills, and civil unions. In many of these areas, he proved to be well ahead of both parts of the PdL, and his stand on these issues certainly put him in difficulties with the Catholic Church. For the probably small number within the AN who shared his views, it might have been helpful when the FLI was formed. But for most it was no doubt a difficult identity to share. 
Having received a degree in psychology, Fini may well have asked himself how he had come to endorse such views. Conceivably, his answer would be that personal views are relative, flexible, and functional to a political role. Fini had prepared his party for a major ideological rethink in 1993 and sailed past the embarrassing contradictions inherent in a long list of his past public statements without much sign of difficulty or embarrassment. In government from 2001-2006, he continued this journey: as the Italian representative to the European Convention in Laeken, he had little difficulty rethinking his earlier Euro-skepticism, and as deputy prime minister, he discovered the full complexity of Italian policy toward immigration control and quickly adjusted the message. That he should show further adaptation as president of the Chamber of Deputies is therefore unsurprising. In Fini's case, the role seems to stimulate the values. One might even infer that his defense of civil rights and of liberal and secular values was preparing him for an even more dramatic break, after which his natural allies would, for the most part, no longer be from the AN at all, but would be found among lay liberals in Forza Italia or even in the liberal center of the political spectrum as a whole. If so, however, Fini played his hand badly, or had his hand forced by Berlusconi. The liberalism on right-to-life issues would hardly find favor with the part of the political center-the Unione di Centro (UdC, Union of the Center) included - that had Catholic origins, and the battle with Berlusconi left Fini with few natural allies in the PdL, even among the liberal wing.

These last observations raise the intriguing question: did Fini go or was he pushed? The two leaders seemed to collide in 2009-2010 with linear inevitability, but it is difficult to decide who had the greater ultimate responsibility for the secession. Berlusconi appears to have isolated Fini from the majority of his supporters quite effectively, an effort that was sustained by an aggressive media strategy. Il Giornale and Libero spared no punches against Fini following the formation of the FLI at the parliamentary level. Fini tried hard to retaliate, both to increase the visibility of his new movement and to discredit Berlusconi, but the FLI had none of the major media control enjoyed by Berlusconi and generally found itself on the defensive in the frequent skirmishes that followed.

Since Berlusconi is not, apparently, averse to risk, he may have been willing to gamble that while the secession might deprive him of his absolute parliamentary majority, it would allow him to prepare for a better future, free of Fini, after another general election, even if the souring of the political climate would rebound against the PdL in the short term. If this was his strategic plan, it almost succeeded. 
However, as we shall see later in this chapter, Berlusconi appears to have been careless in preparing the party organization on the ground to resist the attractions of the FLI-that is, he was either careless or powerless to do much about it.

As for Fini, he might argue that he was indeed pushed. It was, after all, Berlusconi who was the most aggressive actor in public, both at the PdL national council in April and in referring Fini's party allies to the probiviri in July. But Fini played his part in this constant provocation. Either he had been converted to a principled politics in which he finally understood the serious flaws in the coalition partner with whom he had worked for 15 years, which seems unlikely, or he himself was careless, not only in his choice of brother-in-law, but also in estimating how far he could provoke his coalition partner without being thrown out of the party. Clearly, much more evidence is required before this small codicil of Italian party history can be accurately written. We tend to the view that Fini gradually realized after the 2008 general election that his chance of ever leading the PdL was rapidly diminishing and that his psychological reaction to this drew him, perhaps even against his better judgment, into more and more explicit and angry confrontations with Berlusconi. How much advice he was receiving, and from whom, in that psychological journey, offers an interesting possibility for investigation.

\section{Explaining the Split at the Parliamentary Level}

In all, about 11 percent of the deputies and senators followed Fini into the FLI. Who were they and what determined their decision? We note first that the proportion of the PdL following Fini was larger in the Chamber (13 percent) than the Senate (7 percent), possibly reflecting Fini's greater influence where he played an institutional role. As we have seen, most of those who seceded had been in the AN previously, and in this sense the split was within the AN rather than within the PdL. Fini was unable to serve as a wider pole of attraction to discontent in Forza Italia and, in fact, lost the greater part of his own following. The rate of defection to the FLI was slightly lower, although only marginally, for those holding some kind of political office in the AN-PdL than for non-ranking deputies and senators. But Fini certainly did not bring a disproportionate number of leading figures with him. It is possible that those who seceded saw their careers in decline and either had less to lose or hoped to secure more advancement through membership in a smaller universe. However, there does not seem to be an obvious age factor: the average age of the secessionists was 55.7 
years, while that of the AN parliamentarians remaining in the PdL was 54.2. Likewise the parliamentary seniority of the two groups was similar. It might be thought that recent entrants to Parliament would prefer the apparently greater security of the PdL, in that the possibility of re-election would on average be greater, but in fact the proportion of first-time parliamentarians in each camp was exactly the same at just over 25 percent. Those who joined the FLI had, on average, 7.7 years of service in the legislature, while those who stayed with the PdL had 8.6 years. ${ }^{12}$

A further actor-centered explanation of individual choice might lie in the calculations of self-interest arising from the position of each deputy or senator in the list of those elected in 2008. We might expect that the elected AN members who had been placed in more marginal positions in the PdL list had greater incentives to leave the PdL than those who had at least this nominal form of greater security and, other things being equal, whose re-election was less at risk (assuming, of course, that positions in the lists do not change greatly between elections). To test this, we divided the position in the list of each formerAN deputy and senator by the number of elected representatives in each constituency to obtain a positional index (the higher the index number, the less privileged the particular senator or deputy would be in the list). The results do not support the hypothesis that the parliamentarians who remained in the PdL were less marginal than those who joined the FLI. In fact, the position of the AN-PdL parliamentarians is only slightly better $(0.64$ for the AN-PdL against 0.69 for the AN-FLI), and the difference in the index is only 0.04 , which has no statistical significance ( $\mathrm{p}$ value $=0.54$ ).

Looking closely at the geographical distribution of the FLI component in Parliament, we might then seek explanations either in macroregional factors (in particular the competition with the LN), or in a more detailed region-by-region analysis. Obviously, Fini was troubled by the changing relationship of strength within the coalition to the advantage of the LN. The latter had, apparently, found precisely the right formula for playing the dual role of protest party and responsible coalition partner. The League's poll support has gradually expanded since 2008, to a large degree at the expense of the PdL, as table 1.2 demonstrates for the three major northern regions. In the 2008 general elections, the League had almost 21 percent of the votes, compared to the PdL's 32.2 percent; two years later, following the 2010 regional elections, the League had almost 27 percent, compared to the PdL's 28 percent.

Fini frequently sounded his concern about the growth of the League's support, not least at the PdL national council meeting in April, when he accused the PdL in the North of supinely following 
TABLE 1.2 Election results in Veneto, Lombardy, and Piedmont, 2008-2010

\begin{tabular}{lccc}
\hline & $\begin{array}{c}\text { General Election } \\
\mathbf{2 0 0 8}\end{array}$ & $\begin{array}{c}\text { European Election } \\
\mathbf{2 0 0 9}\end{array}$ & $\begin{array}{c}\text { Regional Election } \\
\mathbf{2 0 1 0}\end{array}$ \\
\hline PdL & $32.2 \%$ & $33.3 \%$ & $28.3 \%$ \\
LN & $20.8 \%$ & $22.5 \%$ & $26.5 \%$ \\
\hline
\end{tabular}

Source: http://elezionistorico.interno.it/.

League positions. ${ }^{13}$ The League's growth clearly had implications for the balance of forces on questions of institutional reform-above all, the vexed issue of fiscal federalism. The closer together that Finance Minister Giulio Tremonti managed to draw his joint sponsors, Umberto Bossi and Berlusconi, the bigger the risk to Fini's neo-Gaullist view of national cohesion. It might be supposed, therefore, that the secession of the FLI was also aimed at moderating moves toward fiscal federalism, and that we should expect to see this in a strong southern imbalance in those who backed Fini. Unfortunately, there is no evidence to support this. There is some superficial evidence in the southern backgrounds of leading exponents of the FLI, including Bocchino, Granata, Briguglio, and Adolfo Urso. However, closer inspection changes the picture. In both the FLI and the post-secession PdL, the South accounts for about 40 percent of parliamentarians. Likewise the figure for northerners in both groups is around 37-38 percent. The former AN parliamentarians who stayed in the PdL after the secession show a similar geographical distribution. The North-South argument was certainly not unimportant in the policy arguments that preceded the split, but it does not immediately show up in the backgrounds of those who chose to follow Fini.

A more plausible and nuanced explanation probably comes from a closer analysis of local situations and the on-the-ground control exercised by some of the so-called colonnelli of the AN. We can therefore look at the percentage of defections from the former AN parliamentarians by region. Eight regions have a defection rate higher than the national average of 33 percent. Only in Basilicata did all parliamentarians (two in total) join the FLI. In Basilicata, in fact, the PdL obtained its worst result in the 2010 regional elections, falling from the 34.8 percent it obtained in the general election of 2008, to a miserable 19.4 percent in 2010.

The weakness of the PdL on the ground is reported as having helped to set in motion a large-scale exodus toward the FLI. ${ }^{14}$ In the Marche, Friuli-Venezia Giulia, and Veneto, half or more of the parliamentarians 
followed Fini. The case of Veneto is especially interesting, as it is the only region in which the PdL now runs second to the League (24.7 percent in 2010, compared to the LN's formidable 35.2 percent). In Veneto, two strong supporters of Fini, Urso and Maurizio Saia, had personal strongholds, and this may explain the high level of defection to the FLI (62 percent, or five out of eight parliamentarians), despite the counter-presence of Gasparri and supporters of Altero Matteoli (although the latter's real stronghold was in Tuscany). ${ }^{15}$ Sicily, where 4 of the 10 former AN parliamentarians joined Fini, provides a further interesting case. The Sicilian context is one where there have been major tensions for a long time, not just within the former AN group, but also within Forza Italia. These tensions led to an earlier secession within the PdL, which split into the official PdL and the PdL-Sicilia, and then to a second secession of the Fini group. In the former AN component, the faction led by Granata and Giuseppe Scalia clashed with that of Domenico Nania, the former AN group leader in the Senate and the Sicilian regional coordinator of the PdL. In two other major regions, the Fini secession was much weaker: in Lombardy, the La Russa brothers (Ignazio, the minister of defense, and Romano, a major power broker at the regional and local levels) maintained firm control of the AN wing of the PdL, ${ }^{16}$ and in Tuscany the same control was exercised by the ubiquitous Matteoli and by Denis Verdini.

Thus far, it is evident that we have not tapped any significant variables that provide broad and generalizable explanations about the decision to join the FLI at the parliamentary level. No doubt, personal relationships, social pressure, threats, and opportunities, alongside local political circumstances and regional variations in the political context, all played a role in the difficult choices being made.

We should further note that there is little obvious correlation between the secession of parliamentarians and members of regional assemblies. At least in the early months, it appears that those in the second tier of the PdL (i.e., members of the regional assemblies) were more cautious than the parliamentarians in making any immediate declaration of identity. Outside the special case of Sicily, only 12 members of regional assemblies had, by the end of October 2010, declared their allegiance to FLI, while 316 remained with the PdL. Even adding in the 7 defectors in Sicily, the total comes to only 5.7 percent. It is of course possible that the information is imperfect. The research has depended on Web-based searches of the sources, ${ }^{17}$ which may not be up to date or reliable. However, at the very least, it suggests that regional councilors can afford to wait and watch before making decisions about their future identity. 


\section{The Organizational Resilience of the Popolo della Libertà}

The divisions within the PdL in 2010 raised serious issues about the party's organizational resilience. The threat, and then the reality, of a secession by Fini's supporters created tensions that spread from the leadership to the grassroots. The problems were primarily, but not entirely, between the "Finiani" and the ex-Forza Italia majority. When the split came, the majority of former AN leaders and elected representatives stayed with the PdL, under the informal, although distinct, leadership of Ignazio La Russa and Gasparri. It was not immediately clear whether these two were strengthened and rewarded for staying with Berlusconi, or weakened because they were henceforth leaders of smaller princedoms. But to those from the Forza Italia mainstream, the AN component, even in its potentially reduced state, remained an irritant and a risk, since-with the FLI successfully launched-the possibility of further defections was as acute as ever. The mainstream Forza Italia leadership was also well aware of its own continuing organizational fragility, compared to the experienced organizers and power brokers of the AN, a party with a long tradition of robust organization and discipline. Before their merger, the AN probably had at least twice as many members as Forza Italia. ${ }^{18}$ At the local level, officials in towns and provinces were frequently elected under liste civiche identities that were affiliated with Forza Italia but not strictly part of it. Many of these officials did not have formal membership in Forza Italia, and they continued to sidestep membership in the era of the PdL-a problem that was said to apply even to some parliamentarians. ${ }^{19}$

A further stimulus to organized factional activity arose due to the prominence of Finance Minister Tremonti, whose Forza Italia identity did not preclude ambivalent links with the LN. Tremonti's institutional role as guardian of fiscal probity and his credibility in financial markets gave him a platform and power base far greater in scope than his influence over the PdL, in organizational terms. Here, too, Berlusconi's instincts were divided. He relied on his finance minister's international prestige and status to impose budget discipline, but, as Fini's credibility as successor waned and the press identified Tremonti as the most probable future center-right candidate for prime minister, Berlusconi periodically felt the need to remind Tremonti that there was only one individual who was indispensable. ${ }^{20}$

Media discussions were increasingly framed in terms of the organized factionalism that was characteristic of the Christian Democrat era. The think tank Liberamente, created initially in opposition to FareFuturo and Generazione Italia, remained ostensibly loyal to Berlusconi. Yet even as the FLI group was preparing to depart, other 
groups in the PdL were speaking out and solidifying into a cacophony of voices, more or less openly advising Berlusconi on what he needed to do to avoid party paralysis. Fabrizio Cicchitto's think tank, Riformismo \& Libertà, claimed to defend strands of the liberal and Catholic traditions in a party where they were allegedly at risk. Other forums, including the online newspaper Il Predellino and foundations such as Magna Carta and Italia Protagonista, were more openly platforms for the promotion of personalities.

Officially, business leaders tended to line up behind Berlusconi. However, some, increasingly frustrated by policy stalemates, started making overtures toward Fini. Luca Cordero di Montezemolo, the chairman of Ferrari and inter alia president of Italia Futura, a cultural foundation, published in August 2010 an influential editorial that was sharply critical of Berlusconi's policy-making style and called for a more open and discursive form of government decision-making, as well as more and better-targeted public spending policies. In October, Emma Marcegaglia, one of di Montezemolo's successors as president of Confindustria, also came out with strong criticism of the prime minister. Her attack was not taken lightly in the Berlusconi camp: two journalists from Il Giornale were investigated for threatening to wage a press campaign against her. The incident contributed to a year of increasingly tense relations between Confindustria and the prime minister.

Most critics claimed allegiance to Berlusconi's leadership, but the prime minister and his spokesman, Paolo Bonaiuti, expressed both reservations about the risks of fragmentation and irritation with what was happening to the party on the ground. Eventually, in a surprising outburst in October, Berlusconi put the blame for much of the government's difficulties on the PdL-implicitly, on the three national coordinators, Verdini, Sandro Bondi, and Ignazio La Russa, who were responsible for organizing and managing the party on the national level. ${ }^{21}$ There was also much evident discomfort as a succession of senior PdL figures-including Verdini, Claudio Scajola, Raffaele Fitto, Nicola Cosentino, Stefano Caldoro, and Guido Bertolaso-fell into serious trouble due to various financial scandals. But it was also widely noted that while the typical response (Scajola excepted) was "no resignation," the level of support offered by the colleagues to each other was influenced by internal friendships and rivalries. Fini's treatment at the hands of Il Giornale was in a league of its own, in terms of brutality, and can be seen as part of a general strategy to discredit Fini once the split had been decided. However, among those who remained in the PdL, relationships were also badly affected by the various scandals that emerged in 2010. The serious dispute that arose in November 
between Mara Carfagna, the minister of equal opportunities, and the group dominated by Cosentino, a powerful political boss in Campania, seems to confirm that the interaction between organizational shortcomings and pork barrel politics is negatively affecting the cohesion of the PdL establishment. ${ }^{22}$

Organizational deficiencies and internal indiscipline were perhaps the predictable result of the speed and lack of preparation with which the party had been created. The most startling example was the failure of the PdL to agree on lists of candidates for the administrative elections of 2010 in time to meet the deadlines (in the case of the province of Rome) and with the correct number of valid nominators (in the case of the region of Lombardy), resulting in the PdL's exclusion from the ballot in Rome and mutual recriminations among the opposing factions over the source of blame..$^{23}$ In 2009, these problems had been masked by the warm afterglow of the election victory, but in 2010, following a year in which the leader's image had been severely tarnished, they were becoming difficult to conceal. Moreover, in comparison with European parties such as the Christian Democratic Union of Germany or the British Conservative Party, the PdL's capacity to dominate the center-right and discipline its potential factions into loyalty to the leadership would always be weak. Politicians whose fortunes were in decline in the PdL could realistically think about a profitable defection to another party or breakaway group.

The risk was especially immediate in Sicily, where the PdL lacked territorial organization and was vulnerable to the accusation that it was too accepting of the LN's anti-southern rhetoric. Sicily therefore became a good recruiting ground for the FLI, and Fini was able to build on strong pre-existing relations with parties such as the Partito del Sud (PdS, Party of the South) and the Movimento per le Autonomie (MpA, Movement for Autonomies) and swiftly establish a local organization. Besides the Sicilian splits within the PdL, additional possible escape routes for the disaffected were held out by the UdC and even the League. In 2010, the secession of the FLI added a fourth potential exit point. Under such circumstances, keeping leaders disciplined was hard, and the year saw several reports of grassroots crises in the PdLnot just in Sicily, ${ }^{24}$ but in Puglia, Campania, and Tuscany.

Ultimately, the secessionist problem was not simply the result of structural features of Italy's party system or its electoral process. It was also the outcome of choices concerning ethos and style that had been made by Berlusconi. The iconoclastic culture of the PdL was a carefully chosen contrast to the structured democracy of traditional Italian parties. The PdL's ideal world was one of "promoters," "circles," and "clubs," where supporters materialized spontaneously, even without 
formally joining the party and certainly without the traditional and laborious grassroots work involved in sustaining party networks. Yet real power in the party remained highly centralized. Despite years of debate about normalizing Forza Italia into a structured, internally democratic party, its successor, the PdL, was inevitably organized as a party similarly dominated by elected office-holders and centrally appointed party managers. Holding together a party born of several pre-existing parts obviously required a delicate compromise, starting with its three national coordinators, who represented different perspectives and different constituencies. In this sense, the centralization of power was naturally imperfect. The very delicacy of the power balances that had to be worked out between the national leaders probably made real democratization of the party seem extremely risky.

Equally difficult to sustain forever, however, was the myth of spontaneous mobilization against the reality of pure bureaucratic power. A simple, emotional appeal to the abstract theme of "liberty" was no more motivating to the PdL's would-be promoters than it was to politicians looking for guidance in real-world situations in the regions and cities. The party's leadership showed some realization of this in August, when it set a program of five points: tax reform, fiscal federalism, faster justice, the South, and law and order. But as an agenda for action on the ground, even these points were unlikely motivating forces. The daily decisions of democratic government in a decentralized democracy cannot derive simply from the leader's love of liberty or his infinite capacity to provide the money for elections. Politics at the regional and local levels is about choices in which broad national themes need interpretation and debate. Between elections, a party that depends entirely on impulses from above when appointing its coordinators and regional management will struggle to maintain cohesion and purpose.

For much of 2010, in fact, the PdL seemed to be in a state of near paralysis. It struggled to provide legislative impetus in Parliament as reciprocal vetoes were placed against important legislation. There was bad-tempered debate about which measures in the government's plans had been in the original government program and which (the short trial, in particular) were new. And there was sustained argument about the meaning of fiscal federalism. There were also difficulties over the renewal of the chairmanships of legislative committees, the safest strategy proving in the end to be the renomination of incumbents. ${ }^{25}$ In addition, there was an embarrassingly long wait to appoint a successor to the disgraced Scajola as minister of economic development. Only in October, after the summer break and the defection of the FLI, did the air clear sufficiently for some of these questions to be addressed. 
It would be far-fetched to suppose that in the PdL the combination of a superficial and flawed party constitution and worrying falls in approval ratings were generating a wholesale movement for reform and democratization. Yet these factors undoubtedly emboldened individuals to speak their minds more freely, even if their real concern was for votes, not democracy. The response, as might be expected, was an ambivalent one. Dissatisfaction with the performance of the party locally was reported to be widespread, and one concession that internal critics of the performance of the three coordinators seem to have extracted from the prime minister's office was an agreement to modify the party constitution to allow at least a degree of internal democracy. It was reported that regional coordinators, until then directly appointed by the president of the party according to its constitution, ${ }^{26}$ could henceforth under the right circumstances be elected by an assembly of parliamentarians, regional councilors, and mayors. It was not yet grassroots activism, and it had the proviso (intended to force rival factions to come to local agreements) that a rather high quorum of 70 percent was required. But this decision did at least introduce a small element of locally derived democracy into the excessively centralized party structures. ${ }^{27}$ As for the role of ordinary party members, the situation was less clear. Even as Berlusconi was responding to the concerns of Liberamente and others about the paralysis of the party by ordering a renewed effort to kick-start membership, Bondi was writing an article in which he doubted the future prospects for any party built on individual membership. ${ }^{28}$

\section{Conclusion: After the Vote}

In this chapter, we have presented reasons for the creation of the FLI, both in terms of actor-centered interests and of party ethos and doctrine. Our explanations have been determined largely by the circumstances and activities at the elite level. What will develop on the ground is more difficult to judge, and we have limited ourselves to some brief comments, although the ultimate fate of the FLI clearly depends on its capacity to insert itself locally, to control local networks of power, and thereby to mobilize votes for regional and parliamentary leaders. If it has no prospects of doing so, it will eventually wither and fragment. In this regard, Berlusconi's ability to evade an adverse result in the dramatic confidence vote of 14 December 2010 was a matter of serious concern for Fini, but not the end of the game. At the time of writing-immediately after that vote-there is no simple answer to the question of who won the power struggle 
analyzed here. The parliamentary arithmetic after the secession of the FLI remained finely balanced.

The vote of confidence demonstrated that boundaries of loyalty on the center-right are ill-defined and that switches of party identity are not infrequent. Some individuals are watchful of opportunities and flexible in attachments. Nomination prospects under a closed list system can be important determinants of an individual's direction of travel. Indeed, nomination may not be the only questionable incentive, as was revealed by the polemical debate surrounding the so-called compravendita, that is, the buying and selling of individual deputies. This is nothing new in recent Italian Parliaments, ${ }^{29}$ but the arguments surrounding the integrity of those involved reached new heights in 2010. The conflicts of interest that were brought to light show how urgently Italy needs to address the regulation of this issue.

This fluidity added to the weaknesses of the coalition generated by the FLI secession. The secession happened, by pure chance, to create a very finely balanced parliamentary outcome, one in which several variables would henceforth determine the fate of Berlusconi's coalition. These included the absolute size of the FLI defection; the level of cohesion with which the new group would follow its leader; the cohesion of the PdL itself; the attitude of other "third pole" groups, especially the UdC; and, finally, at the margins, the cohesion even of those deputies who are nominally part of the opposition. When Fini decided to try to bring down the Berlusconi government, he almost attracted enough parliamentarians to his side-but not quite.

In the end, each of the other variables played a role in the vote. The UdC had to decide to join forces with Fini in the confidence vote, which it did, and it had to remain unified throughout the debate and the vote, which it also managed. But others did not, and seven deputies in particular proved decisive to helping Berlusconi avoid defeat. Four of them, extraordinarily, came from the opposition. Two had been elected on the PD list, although one of these, Massimo Calearo, declared that he had "never been on the left," and had started his rightward journey a year earlier, as had a colleague, Bruno Cesario. Two others came from the Italia dei Valori (IdV, Italy of Values) list, one of whom, Antonio Razzi, had been elected to represent one of the overseas constituencies, which have acquired a notable reputation for switching sides. The remaining three, however, were initially supporters of Fini, having joined the FLI in July, only to defect again by December. All were part of the so-called moderates within the FLI, who, throughout the crisis, appeared to have been urging Fini not to make a complete break with the PdL. Rather, they sought an eventual re-entry into the coalition, perhaps along with Pier Ferdinando 
Casini's UdC, if it could be achieved, under a different prime minister. Well before the confidence vote, one of these deputies, Maria Grazia Siliquini, had announced that she would not vote against Berlusconi. It was the dramatic last-minute choices of the other two, Silvano Moffa and Catia Polidori, however, that saved Berlusconi's skin. He had reason to be grateful to both, and there was much speculation that he would be.

The vote of confidence introduced a new phase in the ongoing struggle of the Italian center-right, but it did not resolve the fundamental issue. That issue is the nature of the relationship between a party (the PdL), which aims, thus far unsuccessfully, to hegemonize the coalition, and its challengers (the UdC, the FLI, and of course the $\mathrm{LN}$ ), which seek to create enough electoral space to ensure that the relationship is one of negotiation and co-existence, not hegemony. In 2008, this contest was largely a matter of the relationship between the PdL and the League. Three years later, the game had broadened to include new players and suggested the possibility of a third pole, built around the UdC and the FLI. However, even if the PdL itself, by the end of 2010, appeared to be an increasingly leaky vessel, this new third pole looked anything but watertight, as the confidence vote demonstrated. A decisive turn of events that could provoke an opportunistic rush to the exits, leaving Berlusconi in power, if not exactly in control, remained a possibility, if not a probability. And even if there were no such rush to the exits in 2011, the new pole still had to decide what it wanted to do with its new power-itself no small question.

\section{Notes}

1. The background to the deteriorating relationship between the Forza Italia and AN components of the PdL is described in E. De Giorgio, "The Balance of the Coalition," in Italian Politics: Managing Uncertainty, ed. M. Giuliani and E. Jones (New York: Berghahn Books, 2010), 112-129, here 122-125.

2. See Senato della Repubblica Italiana, http://www.senato.it/composizione/ 21600/159070/152847/genpagspalla.htm.

3. See "Il documento politico del PdL contro i finiani," Il Foglio, 30 July 2010.

4. See http://www.generazioneitalia.it/2010/09/06/avanti-con-futuro-e-liberta/.

5. P. Di Cara, "Fini si organizza: 'Ma niente imboscate,"” Corriere della Sera, 14 May 2010.

6. The four groups that were part of the government majority were the PdL (236 deputies), the LN (59), the FLI (35), and the MpA (5), to whom should be 
added the votes of individual deputies-mostly from the mixed group-in confidence votes when their support was solicited.

7. A. Garibaldi, "Si parte da 15 mila iscritti e 800 circoli," Corriere della Sera, 6 October 2010.

8. P. Di Caro, "Fini: Il Vassallum? Truffa l'ira di Forza Italia," Corriere della Sera, 10 December 2007.

9. Repubblica television, interview of 9 September 2010, http://tv.repubblica.it/ palinsesto/2010-09-09/9352.

10. A. Panebianco, Political Parties: Organization and Power (New York: Cambridge University Press, 1988).

11. See "Decreti, fiducia e immigrazione tutti gli scontri tra Fini e Berlusconi," La Repubblica, 13 January 2009. There were more votes of confidence forced by the government on its legislation in 2009 (10 in the Chamber and 5 in the Senate) than in any year since 1996. See Senato della Repubblica Italiana, http:// www.senato.it/leg/16/BGT/Schede/Statistiche/Stato/2010/DDLQuestione Fiducia.html.

12. These figures refer to the composition of the FLI immediately after the split and may have slightly changed in the following months.

13. C. Dominelli and A. Annicchiarico, "Duro scontro Berlusconi-Fini. Il Premier: Si allinei o è fuori," Il Sole 24 Ore, 22 April 2010.

14. P. Quarto, "Di Lorenzo con Fini, Labriola e gli altri AN restano nel PdL," Il Quotidiano della Basilicata, 3 August 2010.

15. P. Bricco, “La corrente finiana non supera il Po," Il Sole 24 Ore, 24 April 2010.

16. Ibid.

17. The sources are principally the Web sites of the various regional councils.

18. P. Ignazi, L. Bardi, and O. Massari, "Party Organizational Change in Italy (1991-2006)," Modern Italy 15, no. 2 (2010): 197-216. Although any particular annual datum on party membership is likely to be unreliable-especially the PdL figure for as chaotic a year as 2010-the multi-year series in this article bear out our point, showing that from 1997 to 2004, the AN consistently reported at least twice as many members as Forza Italia.

19. M. Cremonesi, "Un rete di fedelissimi per sostenere Berlusconi," Corriere della Sera, 18 June 2010.

20. F. Bei, "Pdl, piano di Berlusconi per evitare il collasso: Capi locali eletti, riparta il tesseramento,” La Repubblica, 17 October 2010.

21. M. Dino, "Berlusconi: Il 'correntismo' 'Non facciamoci del male," Corriere della Sera, 21 June 2010; M. Galluzzi, "Puglia: Il premier riapre i giochi,” Corriere della Sera, 27 January 2010; "Berlusconi striglia il Pdl: Basta errori," Corriere della Sera, 10 October 2010. Bonaiuti was at pains to downplay the significance of Berlusconi's outburst, but after Ernesto Galli della Loggia's observation that the party coordinators had been surprisingly reticent in responding to Berlusconi's critique (E. G. Della Loggia, "La successione a Berlusconi," Corriere della Sera, 18 October 2010), a strong self-defense appeared from both Bondi and Verdini. See S. Bondi, "L'Orgoglio dell'unico partito che vanta una classe dirigente nuova e giovane," Corriere della Sera, 19 October 2010.

22. M. Giannini, “La rabbia di Mara," La Repubblica, 22 November 2010.

23. The affair occasioned a good deal of comment, a special decree from the government, and various judgments from the Regional Administrative Tribunal. See in particular "Il TAR riammette Formigoni," Corriere della Sera, 6 March 2010. 
24. In October, Undersecretary Gianfranco Miccichè formed a new movement, Forza del Sud, to compete with the PdL in southern Italy. See "Micchichá dà vita alla Forza del Sud: A Berlusconi 'Fedeltà non è infinita," Corriere della Sera, 31 October 2010.

25. P. Notargiacomo, "La partita delle Commissioni Parlamentari Fli e Mpa decisivi per le nuove presidenze,” La Repubblica, 5 October 2010; P. Notargiacomo, "Commissioni, l'accordo regge Bongiorno confermata alla Giustizia," La Repubblica, 13 October 2010.

26. Statuto del Popolo della Libertà, Article 26: "The regional coordinator and the vice-regional coordinator are nominated directly by the national president, in agreement with the office of the presidency, in the days immediately following his or her election."

27. F. Bei, "Pdl, piano di Berlusconi per evitare il collasso 'Capi locali eletti, riparta il tesseramento,"” La Repubblica, 17 October 2010.

28. zS. Bondi, "Nel Pdl non sarò io a frenare il rinnovamento," Il Giornale, 12 October 2010.

29. W. B. Heller and C. Mershon, "Party Switching in the Italian Chamber of Deputies, 1996-2001," Journal of Politics 67, no. 2 (2005): 536-559. 